\title{
PÅVIRKER KULTUREN SMERTEN?
}

\author{
Om voldsomme udbrud og diskrete rynker i panden
}

\section{MARIE LOUISE TØRRING}

I sundhedsvæsenet er der en udbredt tendens til at opfatte menneskers smerteadfærd som kulturelt betinget, mens selve smerteimpulsen anses for at være et universelt fænomen, der er ens for alle mennesker. Denne skelnen mellem adfærd/ kultur og impuls/natur kommer ofte til udtryk i den sundhedsfaglige debat, hvor man diskuterer kultur i relation til den tvivl, mange behandlere oplever i forhold til smerteplagede patienter. Som f.eks. i dette temanummer om smerter i Krop \& Fysik fra 2003, hvor man under overskriften „Kulturen påvirker smerten“ kan læse følgende:

En smerteplaget dansker går til lægen. Lad os kalde ham Jensen. Gør det ondt, spørger lægen. Åh, det kan da mærkes, svarer Jensen, stort set uden at fortrække en mine. Men havde den smerteplagede person heddet Mustafa, havde han sandsynligvis jamret og vredet sig af smerte. Forklaringen er ikke, at Mustafa nødvendigvis har mere ondt end Jensen, men derimod at smerte udtrykkes vidt forskelligt fra kultur til kultur (Salomon 2003:10).

Jensen og Mustafa er fiktive personer, men fiktionens hensigt er at oplyse sundhedspersonale (her fysioterapeuter) om ,sande“ kulturelle forskelle. Speciallæge i almen medicin Amneh Hawwa forklarer læserne, at det i mange sydlandske kulturer er helt almindeligt at bruge kroppen til at signalere, at man har ondt: „Derfor får den nogle gange på alle tangenter, når indvandrere opsøger en læge eller fysioterapeut" (ibid.). I bladet opfordres danske behandlere derfor til at vise tolerance og normalisere patienternes ,,voldsomme udbrud, gråd og jammer" (ibid.).

Kulturbegrebets brug og implikationer i sundhedsvæsenet er en udfordring for antropologien. Det rejser nemlig spørgsmålet om, hvordan vi skal forholde os til tvivlen og de iøjnefaldende forskelle i smerteadfærd uden at henfalde til uacceptable kulturstereotyper om Jensen og Mustafa. Denne artikel peger på, at 
det ikke blot er smertens udtryk, men også smerteoplevelsen og smertehåndteringen, der er kulturelt defineret, og at der er en sammenhæng mellem disse elementer i praksis. Med akut smertebehandling i Italien og Danmark som eksempel vil jeg forsøge at præsentere en alternativ forståelse af smertens rolle i det sociale liv. Analyserne bygger på fire måneders feltarbejde på et offentligt hospital i Italien (herefter kaldet det italienske hospital) samt en måneds feltarbejde på et offentligt hospital i Danmark (herefter kaldet det danske hospital). Derudover inddrager jeg observationer fra 14 dages feltstudie på et mindre, dansk regionalsygehus. ${ }^{1}$

Empirien er velegnet til belysning af emnet af flere grunde: I studiet af mennesker i akut smerte må etnografen godt nok affinde sig med, at fortællingerne skrumper ind, og tolkningen retter sig mod sparsomme ord, mimik og kropssprog. Til gengæld giver studiet af akut smertebehandling rig mulighed for at deltage og studere interaktionen mellem mennesker. Dette aspekt går alt for ofte tabt $\mathrm{i}$ antropologisk smerteforskning, hvor især interessen for fænomenologisk inspirerede, narrative analyser tilsyneladende har skabt en præference for interviewbaserede studier af kroniske smertepatienter på bekostning af deltagerobservation som f.eks. i antologien Pain as Human Experience: An Anthropological Perspective (Good et al. 1994). I studiet af akut smertebehandling kan man være med, når reaktionerne finder sted - det være sig patienternes reaktion på smerten, behandlernes reaktion på patienternes adfærd og patienternes reaktion på behandlingen. Ud over at bidrage med et interaktionistisk perspektiv på smerte giver studiet således også et indblik i videnskabens og teknologiens påvirkning af smerteoplevelsen. Sidst, men ikke mindst indgår der i den velkendte opfattelse af danskere og italienere en stereotyp forestilling om nordisk versus sydlandsk smerteadfærd, som italieneren Gino Rocca så fint gør opmærksom på i sit læserbrev til Weekendavisen: „For jer, der ikke skulle vide det i forvejen, så har danskere en højere smertetærskel (en af mine venner fra Rom ville have sagt, at de har gener med nosser ...)“ (Rocca 2006). Brugen af kulturstereotyper begrænser sig således ikke kun til litterære fremstillinger i den sundhedsfaglige debat, men er, som det vil fremgå, i høj grad udtryk for en almen forståelse af forskelle blandt informanterne i felten. Det sætter den sædvanlige antropologiske kritik af det essentialistiske kulturbegreb under pres og fordrer nye svar på spørgsmålet: Påvirker kulturen smerten?

I de følgende afsnit reflekteres over svaret på følgende vis: Først føres læserne ud i verden til en afdeling for intensive brandsårspatienter i Italien. Tvivlen i denne felt giver med inspiration fra filosofien og lingvistikken anledning til at diskutere, hvordan man som behandler, etnograf eller bare ganske almindeligt menneske er i stand til at erkende andre menneskers smerte. Måden at tvivle på for- 
drer også en bedre forståelse af materialiteten og historiciteten i akut smertebehandling. Her introduceres aktør-netværk-teorien som en alternativ måde at forstå dynamikken mellem patient og behandler på. Derefter sendes læserne hjem til et observationsafsnit for postoperative patienter på det danske hospital, hvor jeg med inspiration fra antropologien vil tydeliggøre, hvordan smerte er påvirket og formet af kollektive forestillinger om korrekt og passende smerteadfærd. ${ }^{2}$

\section{Det italienske hospital}

Brandsårsafdelingen på det italienske hospital ligger på 10. og øverste etage af en grå betonbygning. Ud for knap nr. 10 i elevatoren har en eller anden ridset ,il purgatorio“" (skærsilden) i metallakken - en rammende betegnelse for stemningen og atmosfæren på afdelingen. Stuerne er nøgne, kolde, uden vinduer og oplyst af neonrør. Alt apparatur, vægge, gulve og lofter er slidte og grå. Midt på gangen ligger et overvågningslokale, hvor man kan følge patienterne på tv-skærme. Her holder personalet til. Afdelingen har to personalegrupper. Lægegruppen udgøres af tre mandlige plastikkirurger, Sossi, Mughetti og Baldino, samt overlægen, il Primario, der for det meste gemmer sig på et mørkt, men komfortabelt kontor. Lægerne tager sig af kirurgien og går stuegang en gang om dagen. Plejegruppen, der arbejder i fireholdsskift, tager sig af den daglige kontrol, omsorg, pleje og behandling af de intensive patienter. Hovedparten af plejerne er mænd. De er ikke specialuddannede, og deres opgaver er praktisk orienterede: De renser sår, forbinder, skifter sengetøj, serverer mad og noterer patienternes indtag af og udskillelse af medicin, mad og væske.

Det er dr. Baldino, der har inviteret etnografen indenfor i håb om, at hun måske kan finde en forklaring på, hvorfor ingen interesserer sig for smertebehandling på afdelingen. Som det eneste sted på det italienske hospital har han forsøgt at implementere smertescoring for at fremme opmærksomheden på smerte. Det betyder, at plejerne hver anden time skal spørge patienterne, hvor ondt de har på en skala fra 0 til 10 og nedfælde oplysningen på et observationsskema under teksten ,il dolore“ (smerten) side om side med registreringer af blodtryk, puls, iltprocent, indtag af vand, mad, vitaminer og medicin, udskillelse af urin og afføring m.m. Baldinos indsats har dog ikke båret frugt - smertekolonnen står altid gabende tom.

På brandsårsafdelingen bliver smerte sjældent kommunikeret via en regulær samtale. Hjerteskærende skrig og gråd er en del af hverdagen, især om formiddagen, hvor la medicazione finder sted, og patienterne får renset sår og lagt nye forbindinger. Det er tydeligt at se og høre, at patienterne lider, men ikke desto mindre bagatelliserer personalet ofte patienternes smerte, hvis de ikke ligefrem 
reagerer med en mur af tavshed på den voldsomme jammer. Et godt eksempel er denne episode med patienten Sofia, der ligger isoleret og indhyllet som en mumie i hvide bandager på en lille enkeltsengsstue for enden af gangen. Sofia er i 50'erne og kommer fra Napoli. Hun tabte en cigaret ned i en spand maling, mens hun ferniserede sin hoveddør, og blev indlagt med svære andengradsforbrændinger over $60 \%$ af kroppen. Kirurgerne har for at forhindre væsketab måttet transplantere hud, der er fastgjort med metalklips, til de mange brandsår. En dag beslutter Baldino, at Sofia skal have det stærke smertestillende middel fentanyl, ${ }^{3}$ mens hendes forbindinger skiftes. Det er et tilfældigt lune, siger sygeplejerne Paolo og Eugenio, der skal effektuere behandlingen. De plejer for det meste ikke at give supplerende smertestillende. Behandlingen forløber således: Som opstart får Paolo besked på at give en intravenøs injektion af 3 mikroliter fentanyl og derefter forsætte med 1 mikroliter hvert andet minut, men efter første injektion stiller plejerne sig ud i forgangen og snakker. Sofia ved tilsyneladende godt, at behandlingen ikke hjælper, hvis hun ikke hele tiden får en ny dosis. Hun sukker og ryster på hovedet, mens hun ser skælvende ud på de to mænd. Da de kommer tilbage efter et kvarter og begynder at rykke bandagerne af, stønner hun: „I har snydt mig! Giv mig én til!“ De griner lidt, for det virker underligt, at en patient forlanger medicin, det har hun ikke mandat til. Eugenio svarer åndsfraværende: „Hvad, har fentanylen ikke hjulpet?“

Under Sofias baller gemmer sig et stort blødende sår. Da bandagen er fjernet, blødes sårskorperne op med fugtige jodklude, og sygeplejerne holder pause. Jeg spørger Sofia, om hun har ondt. "Ikke nu, men før! Der findes ingen ord for det, jeg var næsten død.“ Jeg beder hende beskrive smerten, men det kan hun ikke, den er ubeskrivelig. Jeg forsøger at give et par bud: „Svier det, brænder det?“, men Sofia ryster på hovedet og gentager med tårer i øjnene: „Maria, den fysiske smerte ... jeg kan ikke holde det ud længere.“

Baldino kommer nu forbi igen og ser på sårene og beordrer bentaminsalve (et desinficerende middel). Så spørger han plejerne, om de følger hans fentanylinstruks. Begge er fuldt beskæftigede med bandager, salve, sakse og blodigt affald, de mumler lidt og ryster på hovedet. Baldino kaster armene op i vejret, skælder ud og slår sig for panden for at vise dem, hvor dumme de er: „Det har absolut ingen effekt, hvis I glemmer det! Nu skal der gives høje doser igen! Giv hende 2 mikroliter til!!!‘ Paolo slipper det, han har i hænderne, og giver Sofia endnu en injektion. Baldino er på vej ud af døren, da Sofia kalder: „Hr. læge, jeg har forfærdeligt ondt!“ „Hvad?“”,Jeg har forfærdelig ondt!“ Han ryster på hovedet og forsvinder uden at svare hende. Der går 10 minutter, så begynder Sofia at kalde på Paolo: „Paolo, Paolo giv mig én til!“ Fem gange skal der til, før han reagerer, for han diskuterer fodbold med Eugenio. Der går syv minutter, og in- 
gen har kontrol med smertebehandlingen. Sofia klager, brokker og blander sig: „Ajaaa, aaarrrgghhhh iaiiihhhh ohhhh, AJAAJA AJA.“ Paolo kigger opgivende, men også sødt på hende og korrigerer hendes opførsel: „Undskyld mig Sofia, men du er ved at hele!“

\section{Om erkendelse af smerte}

Margaret Mead skriver i et forord til Mark Zborowski's monografi People in Pain: „Skriget afægte smerte kender ingen sproglige grænser, og modet under nålen og kniven behøver ingen fortolkere“ (Mead i Zborowski 1969:ix). ${ }^{4}$ Hermed hævder hun, at der faktisk findes et universelt udtryk for smerte, som alle mennesker forstår på tværs af sprog og kultur, nemlig det instinktive skrig af akut, fysisk smerte. Besøget på det italienske hospital gjorde det dog hurtigt klart for mig, at skrig kan være genstand for utallige og modstridende tolkninger. Behandlerne var aldrig entydige på dette punkt. De klassificerede gerne patienterne som typer, f.eks. ,psykisk syge“, „gamle“, „, følelsesladede“, „traumatiserede“, „,forkælede“, „sydlændingene“, „tredjegradsforbrændte“ eller ,typisk kvinder“, og lod tolkninger af smerteadfærd indgå i et bestemt videnshierarki om patientens fysiske og psykiske tilstand samt sociokulturelle baggrund. En hyppig smertetolkning angik omfanget eller graden af kropslig skade. Behandlerne gjorde f.eks. inkonsistent og ambivalent brug af deres viden om tredjegradsforbrænding, der efter sigende beskadiger nerveenderne så meget, at man mister evnen til at føle. Nogle gange roste de patienternes stoiske smerteadfærd, selv om man kunne stikke en finger lige ned såret, uden at patienten reagerede (som kirurgen Mughetti bl.a. var venlig at demonstrere for mig en dag). Andre gange irettesatte og tyssede de på såkaldte hysteriske patienter, fordi de ikke mente, der var tale om reelle, fysiske smerter. Personalet mindede mig også om, at det italienske hospital modtog patienter fra hele Syditalien, Balkan og Mellemøsten - underforstået, at her behandlede de typiske sydlændinge, der var yderst tilbøjelige til at teatralisere og overdramatisere deres smerte. „Jo længere mod syd, jo mere skaber de sig!“ forklarede Baldino og påpegede, at skrigeriet var som en slags musik for de sydlandske patienter - man kunne ligefrem fornemme den pulserende rytme i deres klagesang, hvilket gjorde det umuligt at tyde deres tegn.

Den amerikanske sprogprofessor Elaine Scarry, der har analyseret den fysiske smertes sprog i det filosofiske værk The Body in Pain. The Making and Unmaking of the World (1987), gør opmærksom på en uoverskridelig grænse mellem det „at føle smerte“ og det ,at erkende et andet menneskes smerte“. Det første gør vi ubesværet og uden videre, mens det andet er os næsten umuligt: 
Lige så ubestrideligt nærværende det er for en smerteplaget 'at have smerte', hvilket man kan tænke som det stærkest tænkelige eksempel på, hvad det vil sige 'at have vished' - lige så uhåndgribeligt kan det være for et andet menneske 'at høre om smerte', som derfor kan være et rent udtryk for, hvad det vil sige 'at være i tvivl' (Scarry 1987:4). ${ }^{4}$

Følger man Scarrys argument, er det nærliggende at betragte behandlernes modstridende tolkninger som udtryk for netop denne grundlæggende tvivl, der udspringer af menneskets manglende evne til at erkende andre menneskers smerte. I felten er der dog forskel på etnografens og behandlernes tvivl. I situationen læste jeg umiddelbart Sofias adfærd som udtryk for en forfærdelig smerte, for jeg havde aldrig i mit liv set eller hørt noget lignende. Kun personalets manglende reaktion gjorde mig i tvivl. Hvad indebærer etnografens tolkning, kunne man derfor med rette spørge? Selv om jeg ikke tvivlede på patienternes smerte, hverken ved lyden af deres skrig eller synet af deres sår, så må jeg indrømme, at jeg på brandsårsafdelingen oplevede en vis metodologisk magtesløshed i mødet med patienterne, som når Kleinman og Copp skriver: „Når vi mangler følelsen af fordybelse, føler vi os uautentiske“ (Kleinman \& Copp 1993:10). ${ }^{4}$ Mine forventninger til mig selv som etnograf gik på evnen til at leve mig ind i patienternes smerte og benytte den narrative analyse til at nå ind til kernen i patienternes smerteerfaring som beskrevet af Kleinman:

[Det] er muligt at tale med patienter - selv de, som lider mest - om den faktiske sygdomsoplevelse, og [...] ved at være vidne til og hjælpe med til at bringe orden kan denne oplevelse have terapeutisk værdi (Kleinman 1998:xi). ${ }^{4}$

Men hvad gør man, når data begrænser sig til lyde (argghh, aaja aaja, åhhh), ansigtsudtryk (lukkede øjne, rynket pande, trillende tårer) og et begrænset udvalg af ord som ,ild“ og „det brænder“. I mit forsøg på at tolke det ubeskrivelige oplevede jeg, at den narrative analyse kom til kort som erkendelsesmæssig tilgang til informanternes smerteoplevelse, fordi jeg i hermeneutisk eller fænomenologisk forstand ikke kunne leve mig ind i et ,ajaaa, aaarrrgghhhh iaiiihhhh ohhhh, AJA AJA AJA“. Scarry skriver meget rammende om denne oplevelse, at den fysiske smerte undviger sproget eller „,modsætter sig sproglig objektgørelse“ (Scarry 1987:5). ${ }^{4}$

Set i dette lys, så egner studiet af mennesker i akut smerte sig næppe til en antropologi, der lever af at føle sig ind på andre menneskers verden (Hastrup 2004:17), men det betyder ikke, at den akutte smerte og den adfærd/det udtryk, der er forbundet med den, er universel og givet på forhånd, som mange antropologer ellers antager (Kleinman et al. 1994:3; Finkler 1994; Free 2002; Helman 2000; Zborowski 1969). Ifølge lingvisten Konrad Ehlich begrebslig- 
gør vi i alt for høj grad smerte som en instinktiv, indefrakommende og dermed personlig og privat følelse eller erkendelse, der isolerer det lidende menneske fra hans eller hendes omgivelser (Ehlich 1985:179). Inspireret af Wittgenstein gør Ehlich opmærksom på, at alle former for smerteudtryk bygger på appel til omgivelserne og således bør tolkes i lyset af deres funktion og $i k k e$ afskrives i manglen på regulært, syntaktisk sprog:

Medens smerte i den filosofiske analyse har fremstået som et af de mest enestående, solipsistiske fænomener, så er smerte ud fra et sprogligt synspunkt primært et interaktionelt fænomen og ikke en solipsistisk følelse. En smerte, der opleves, bliver i de fleste tilfælde udtrykt (op.cit.:180). ${ }^{4}$

Såvel akustiske som visuelle smerteudtryk er appellerende og gør smerte tilgængelig for andre mennesker ved at sætte mentale processer i gang hos modtageren, der former hans eller hendes sympati samt vilje og ønske om at hjælpe. Selv det mest elementære skrig har således en interaktiv funktion. Den første delkonklusion må således være kontra Margaret Mead, at tvivlen er et grundlæggende element i erkendelsen af andre menneskers smerte, men tolkningen afhænger af modtageren.

\section{Om aktører og netværk}

På dette hospital er vi et par skridt bagud, hvad angår postoperativ smertebehandlingskontrol. Jeg tror, vi gør 30-40 \% af det, man ville kunne gøre. Det er et spørgsmål om antal af sygeplejersker og om kultur, både lægernes og sygeplejerskernes [...]. Det kulturelle, tekniske aspekt ved lægens brug af farmaka, ikke mindst opioider, er virkelig en kulturkløft - i hvert fald i vores kultur, hvor man indtil for få år siden kun gav opioider til terminale patienter (interview med ledende overlæge på anæstesiologisk afdeling, det italienske hospital).

I dette citat benyttes kulturbegrebet ikke om forskelle i patientadfærd, men derimod til at forklare forskelle $\mathrm{i}$ behandlernes måde at håndtere smerte og smertebehandling på. Med „kultur“ henviser den italienske anæstesiolog til en generel modvilje i det italienske sundhedsvæsen til at benytte opioder. ${ }^{5}$ Den medicinske brug af stærke smertestillende midler var indtil 2001 underlagt vidtgående regulativer af frygt for misbrug og videresalg, og Italien har den dag i dag et af Europas laveste, legale forbrug (Zenz \& Willweber-Strumpf 1993; Chinellato et al. 2003). Til sammenligning bør nævnes, at Danmark har et af verdens højeste forbrug af opioider og udskriver i den primære og sekundære sundhedssektor tilsammen ca. 20 gange mere morfin end Italien (International Narcotics Control Board 2001). Det er måske en billig, men vigtig pointe, at Sofias subjektive 
kvaliteter, kompetence og personlighed er fanget i det, anæstesiologen her kalder kultur. Hendes smerteadfærd virker dramatisk, men placerede man hende på Rigshospitalets brandsårsafdeling i Danmark, ville hun blive lagt i fuld narkose og dermed ophøre med at intervenere i smertebehandlingen. ${ }^{6}$

Antropolog, filosof og primus motor inden for science studies og aktørnetværk-teori (ANT), Bruno Latour, har kritiseret „den store kløft“ (Latour 1999:97) ${ }^{4}$ i videnskaben, dvs. den moderne trang til at skelne mellem objekt/ $\mathrm{krop} /$ natur og subjekt/sind/kultur), og i stedet argumenteret for en symmetrisk antropologi, der giver objekter og subjekter ligelig plads i den antropologiske analyse (Latour 2000:182). Latour ville betragte en skelnen mellem smerteadfærd og smerteimpulser som henholdsvis partikulære kulturfænomener og universelle naturfænomener som en regulær misforståelse. I ANT fokuseres på sammensuriummet og sammenblandingen af teknikker, personligheder, objekter, subjekter, naturer og kulturer, hvilket gør perspektivet egnet til at analysere netop smertebehandling. Latour benytter fællesbetegnelsen aktanter (,actants“, op.cit.: 194) om mennesker og ikke-mennesker (,nonhumans“, ibid.) for at undgå uhensigtsmæssige dualismer og understrege, at mennesker ikke er alene om at handle. „Ansvaret for handling skal deles mellem de forskellige aktanter“ (ibid.), ${ }^{4}$ fordi ikke-mennesker (objekter/ting/teknologi) har mål eller funktioner, der bringer dem i konstant interaktion med mennesker. Med fokus på ikke-menneskers handlekraft gør Latour endvidere opmærksom på kvasiobjekter („quasi-objects“, Latour 1999:51-5) og hybrider („hybrids“, op.cit.:41-3) i de videnskabelige felter, han studerer. Han ser natur og kultur som værende uløseligt forbundet - individet lever ikke i samfund af mennesker, men i kollektiver (,collectives“, Latour 2000: 304) forstået som komplekse samlinger af naturer-kulturer (,natures-cultures“, Latour 1999:104-6) af ikke-mennesker og mennesker.

Betragter man smerteoplevelsen og smerteudtrykket i dette perspektiv, bliver det klart, at Sofias stemme tilhører kollektivet på brandsårsafdelingen, hvor skrigene er et sprog, der udspringer af reelle sensoriske oplevelser af vævsskade, men modificeres og reguleres løbende i interaktion med behandlerne $o g$ behandlingen. Videnskab og teknologi spiller her en central rolle, hvilket også antydes i den italienske anæstesiologs udtalelse om at være ,et par skridt bagud, hvad angår postoperativ smertebehandlingskontrol“. Ifølge den ANT-inspirerede sociolog Isabelle Baszanger (1998a og b) har det kliniske blik på smerte ændret sig markant siden midten af 1900-tallet i takt med udviklingen af nye anæstesiologiske teknikker og ikke mindst smerteteorier. I lægevidenskaben er man gået fra at betragte smerte som et symptom og nødvendigt onde, til at se smerte som en sygdom „i sig selv“ (Loeser \& Bonica 2001, Baszanger 1998b). Det skyldes især Melzack og Walls lancering af gate control-teorien i 1965, hvor smertemekanis- 
men beskrives som en port i rygmarven, der kontrollerer og regulerer, hæmmer og stimulerer smerteimpulser (Melzack 1993). Den nye smerteforskning peger på, at vores hjerne eller bevidsthed er med til at regulere smerteimpulserne, der derfor ikke bør betragtes som absolutte størrelser, men som fænomener, der er afhængige af subjektive faktorer såsom opmærksomhed, angst eller koncentration (Loeser \& Bonica 2001). Dette paradigmeskift har haft enorm indflydelse på behandlingen af især kroniske smerter, der i dag håndteres i multidisciplinære smertecentre med så forskellige behandlingsformer som analgetiske blokader, neurokirurgi, antidepressionsbehandling, akupunktur og kognitiv terapi (op.cit.:255).

Indtil for relativt få år siden blev akutte smerter stadig betragtet som mere eller mindre symptomatiske, fysiske tilstande og derfor overladt til kirurgerne, men også dette har ændret sig markant. I slutningen af 1980'erne varsler den internationale smerteforskning præventiv og vedholdende behandling af akutte smerter. I teorien mener man, at ukontrollerede, akutte smerter kan udvikle sig til kroniske smerter (betegnet „,smertens onde cirkel“, Carr 1993:2), ${ }^{4}$ samt at akutte smerter hindrer sårheling, skaber psykisk demotivation, forlænger indlæggelsen og koster penge (Chestnut 2000; Donovan et al. 1987; Frølund 1996; Gould et al. 1992; Kehlet 1989). Ændringen i den akutte smertebehandling er dog lige så meget teknologisk som teoretisk betinget. Nyudviklede, potente opioider med hurtigt aftagende effekt som fentanyl har betydet, at patienter er vågne og potentielt har akutte smerter umiddelbart efter operationen. Kontrollen over akutte smerter kræver derfor omhyggelig planlægning og vedholdende medicinering, hvilket igen fordrer flere smertebehandlere (Hatfield et al. 2003:130). I de seneste år har man i sundhedsvæsener verden over forsøgt via kampagner at synliggøre, vurdere og dokumentere akut smerte på hospitalerne - det gælder også på det italienske hospital, hvor regionen netop havde startet kampagnen „Un ospedale senza dolore“ (et hospital uden smerte), da jeg begyndte mit feltarbejde i 2003.

Med begrebet ,kulturkløft“" refererer den italienske anæstesiolog således også til forskelle i viden, eller rettere til et paradigmeskift fra synet på smerte som et symptom og nødvendigt onde til synet på smerte som en uacceptabel og skadelig tilstand. Behovet for overhovedet at promovere et hospital uden smerte er udtrykt for, at langtfra alle kirurger og anæstesiologer var „omvendte“ i 2003. Flere informanter påpegede $\mathrm{dog}$, at den primære forhindring for paradigmeskiftet ikke var manglen på teknologi og viden, men manglen på menneskelige ressourcer. Ved at tage højde for konteksten af teknologiske, historiske, økonomiske, kulturelle og sociale vilkår giver ANT-perspektivet en udvidet forståelse af smerteoplevelsen og smertehåndteringen, der er uløseligt forbundet med selve smerteudtrykket. På brandsårsafdelingen kan fentanylen ikke interagere med Sofias smerteimpulser, 
når sygeplejerskerne ikke har frie hænder til at lade stoffet indgå i dynamikken. Både dr. Baldino og sygeplejersken Paolo drømmer om at få en anæstesiolog tilknyttet afdelingen - en hybrid, der organisatorisk, teknisk og farmakologisk kan sikre smertebehandlingen og lindre patienternes voldsomme smerter. Sofias skrig skal derfor ses i relation til manglen på smertestillende midler, i relation til hendes angst og traumer fra brandulykken, i relation til de gældende normer og retningslinjer i og uden for kollektivet samt i relation til konventionelle måder at opfatte og udtrykke smerte på. For at underbygge denne pointe vil jeg nu sende læserne hjem og undersøge, hvilke typer der skabes af forbindelsesrækkerne mellem mennesker og ikke-mennesker på det danske hospital.

\section{Det danske hospital}

På det danske hospitals observationsafsnit taler man dæmpet og sørger for ,ro omkring patienten“. Lyset skinner gennem høje vinduer og dæmpes af de blomstrede gardiner, der i forårets farver skaber et blødt, varmt og afslappende lys på stuen. Her befinder patienterne sig i transit mellem operationsgangen og sengeafdelingen. De skal observeres og smertedækkes. Hver sengeplads er udstyret med alt det overvågningsapparatur, hjertet kan begære: iltapparater, sugeapparater og smarte monitorer, der løbende viser puls, blodtryk og iltmætning i blodet. Målingerne nedfældes i et skema hvert kvarter og indgår i en samordnet og reguleret vurdering af patientens indre og ydre stabilitet. Stort set alle følelser af ubehag kan afhjælpes lige fra kulde, kriller i halsen, kvalme og anspændthed til pulserende, gennemborende og sønderrivende smerter. Mængden af hjælpemidler er stor: varmetæpper, kolde omslag, pøller, isvand, vaniljeispinde, beroligende musik, Panodil, morfin, ${ }^{7}$ fentanyl, Zofran ${ }^{8}$ og Dormicum. ${ }^{9}$ Personalets høje uddannelsesniveau afspejler sig i de mange repræsenterede subspecialer på stuen. Man møder både opvågnings-, observations-, intensiv-, anæstesi-, operations- og smertesygeplejersker. Tre observationssygeplejersker fra afsnittet har sammen udarbejdet retningslinjer for den postoperative smertebehandling, der følger internationale anbefalinger om såkaldt præventiv smertebehandling. Den indbefatter bl.a. en målbeskrivelse: Målet med smertebehandlingen er, at patienterne skal have en smertescore under 3 i hvile og under 5 ved hoste, vending og mobilisering samt ,, et smerteniveau, der er acceptabelt for patienten“. Det kræver i teorien, at personalet skal smertescore patienterne mindst fire gange i timen.

På observationsafsnittet gør akustiske, visuelle, men tilsyneladende også numeriske udtryk smerte tilgængelig for andre mennesker. En italiensk ortopædkirurg mente, at smertescoring måtte være særlig relevant i Nordeuropa, fordi patienterne ikke gav udtryk for deres smerte, men mente til gengæld, at instrumen- 
tet var overflødigt i Italien, hvor patienterne ganske enkelt skreg, når de havde ondt. Der er godt nok meget stille på observationsafsnittet, men stilheden skyldes ikke manglende kommunikation. På observationsafsnittet har man først og fremmest implementeret smertescoring med henblik på at udvide ordinationsretten (lægernes monopol på medicinudskrivning), så sygeplejerskerne lettere kan udføre præventiv smertebehandling, der går ud på at opretholde mætningsdosis af de smertestillende stoffer i blodet, så patienterne ikke oplever gennembrudssmerter. Det kræver kontinuerlige injektioner eller „titrering“, som plejerne kalder det. Når en postoperativ patient ankommer til afsnittet, skal behandlerne ifølge retningslinjerne bede patienten om en smertescore hvert tredje minut. Begyndende svage smerter kan være tegn på et fald i mætningsdosis, derfor gives der morfininjektioner, hvis patienten svarer 4-6, mens en score på 7-10 giver det trænede plejepersonale ret til at anvende sågar fentanyl. Når smerterne er under kontrol (0-3), beder behandlerne kun om en smertescore et par gange i timen. Behandlerne opfatter selv brugen af smertescoring som et udtryk for, at de tror på patienten og ønsker at give patienten indflydelse på smertebehandlingen, som denne sygeplejerske forklarer:

Du kan ikke føle et andet menneskes smerte, det kan du ikke føle, og det er jo derfor, vi bruger smertescoren, fordi, som jeg også siger til dem [patienterne]: 'Jamen du er nødt til at fortælle mig, hvad det er, du føler, for jeg kan jo ikke mærke, hvor ondt du har!' Og vi er nødt til at tro på, at det, patienten siger, at det er det. Selv om patienten måske ikke ser ud til at have så ondt, så er vi nødt til ... Hvis patienten føler en smertescore på 7 , jamen, så er det det, og så skal vi behandle ud fra det (Else, opvågningssygeplejerske).

Som det fremgår, er tvivlen også til stede i dette kollektiv, og i den daglige praksis handler smertescoring i høj grad om at finde et fælles sprog. Mange sygeplejersker relaterer skalaen til noget, patienterne kender i forvejen, ved f.eks. at bede dem give deres smerte en karakter eller bruge smertens richterskala, hvor 0 er ingen fare, og 10 er det helt store jordskælv. Smertescoring har derved karakter af at være en slags laveste fællesnævner i klinikken, for ,,alle kender til karakterer, det har de prøvet i skolen“. Alligevel opstår der ofte misforståelser og akavede situationer, fordi patienterne ikke er fortrolige med den numeriske kommunikationsform, som denne lille episode fra regionalsygehuset viser. Opvågningssygeplejersken Else smertescorer en patient, Rita, der netop har fået kejsersnit og er blevet steriliseret. Rita virker lidt mut, men klager sig ikke.

Else: Prøv at give din smerte karakter på en skala fra 0 til 10, hvor 0 er ingen smerte, og 10 er den værst tænkelige smerte!

Rita: Så er det 10! [griner]. 
Else: Kan du overhovedet ikke få det værre?

Rita: Jooo, men det er jo efter min smertetærskel! [smiler].

Else forklarer tålmodigt systemet igen. Patienten tænker sig om længe.

Rita: Jamen, så er det jo højt, deroppe, måske 7, 8 eller sådan noget.

Else: Jamen, så skal du også have noget mere [morfin].

Else hvisker i etnografens øre et par meter væk fra patienten.

Else: Du kan nok se, man skal ikke tro på alt, hvad man hører! Man skal stole på sit kliniske blik!

Etnograf: Hvad fortæller dit kliniske blik dig?

Else: Jamen hun har det da skidt, men det er ikke, fordi hun har ondt, det er også situationen, hun har det skidt i kroppen, hun har det ikke godt.

Som Rita så fint gør opmærksom på, afhænger tallet også af personen. Selv om Else ikke vil indrømme det, mens hun står ved patienten, peger hendes bemærkning om det kliniske blik på, at smertescoring ikke er hendes eneste indikator for Ritas postoperative smerteintensitet. Flere behandlere giver udtryk for, at smertescoring falder dem unaturligt og hæmmer deres evne til at smertebehandle, for hvis de skal have hele personen med, som de siger, kan de ikke nøjes med et tal på en skala. Behandlernes største problem og udfordring er ifølge dem selv, at de ikke kender deres patienter, før de pludselig ruller ind på stuen. De har et stort ønske om at tilpasse smertebehandlingen den enkeltes (individets) behov. Patienternes transit fordrer således lyntolkninger og blik for personlighed. En mandlig sygeplejerske fortæller denne historie som eksempel på, hvordan han smertebehandler. Det er et godt eksempel på, hvor mange detaljer i patientens udtale, ansigt og journal m.m. der egentlig inddrages i behandlerens tolkning:

Jeg fik en patient, der havde fået fjernet blindtarmen. Hun virkede meget lukket, men hvilede sig og så ikke ud til at have smerter. På et tidspunkt fik hun en stor rynke i panden. Jeg spurgte, om hun havde ondt, og hun svarede ja. Jeg benyttede skalaen, som jeg havde introduceret fra starten, og patienten lå ret højt, så jeg gav hende fentanyl flere gange, men rynken forsvandt ikke. Til sidst tolkede jeg på nogle oplysninger fra journalen. Pigen havde en kronisk tarmlidelse - måske var hun bekymret eller havde dårlige erfaringer med i bagagen. Jeg gik direkte til hende, for man må aldrig være bange for at konfrontere sig med patienten, og spurgte hende, om hun var nervøs. Hun var meget bekymret og ked af det. Disse spændinger kan meget vel være det, der giver hende smerter, derfor gav jeg hende en knivspids Dormicum, så hun bedre kunne slappe af. Resultatet var, at pigen sov i bare 10 minutter, og da hun vågnede, havde behandlingen virkelig hjulpet efter hendes eget udsagn (fra interview med sygeplejersken Claus på observationsafsnittet).

Sygeplejerskernes metode til at forstå patientens smerte er ikke intuitiv, objektiv eller fordomsfri. Den slægter etnografens metode på, forstået således, at syge- 
plejerskerne samler informationer med arme og ben: alder, blodtryk, diagnose, erhverv, førstehåndsindtryk, kultur, kulør, køn, medicinforbrug, puls, personlighed, placering i sengen, rynker, sygehistorie, temperament, udseende m.m. Alt inddrages, kobles og tolkes for at skabe et helhedsindtryk af patienten og træffe en beslutning. Som sygeplejersken Kirsten formulerer det: „Jeg bruger meget sådan en cocktail af mange ting!“

Den amerikanske antropolog John Leavitt har kritiseret empatibegrebet i følelsesantropologien (,the anthropology of emotion“ repræsenteret ved f.eks. Renato Rosaldo (1984) og Joel Davitz (1969)). Han påpeger, at ideen om empati - at man kan sætte sig ind i et andet menneskes følelser - bygger på en forkert antagelse om, at vores intuition eller førstehåndsindtryk er sande. I virkeligheden, siger Leavitt, dækker førstehåndsindtrykket over et bredt udsnit af materiale som barndomsminder, livssituationer, kulturelle forventninger, myter, definitioner, observerede følelser, bevægeapparatets fysiologi m.m. (Leavitt 1996: 527). Når vi ønsker at tolke, forklare eller forstå et andet menneskes følelser, kobler vi automatisk til dette materiale, og det er denne proces, etnografen skal gøre sig bevidst. Denne måde at forstå smerte på kalder Leavitt sympati, beskrevet som en bevidst med-følelse frem for en ukritisk ind-føling, der ligger implicit i empatibegrebet (ibid.). Denne kritik kan også rettes mod behandlernes idé om det kliniske blik. Behandleren har ikke et neutralt blik for smerten, men erkender patientens smerte ved at bruge sit eget materiale og sætte det i relation til den kontekst, patienten er en del af. Derigennem konstrueres en forståelig og meningsgivende model for patientens oplevelse. Holder man som etnograf øje med disse meningsgivende modeller, bliver det særligt tydeligt, hvordan mennesker og ikke-mennesker i fællesskab er med til at skabe bestemte stemninger, personligheder, smerteoplevelser og smerteadfærd.

På det danske hospital er de internationale anbefalinger om præventiv smertebehandling omformuleret til et dybtfølt ønske om, at patienten ,har det godt“ og „,er sig selv“. „Her behandler vi ikke patienternes smerte, vi forebygger den“ lyder det fra sygeplejersken Hanne på øre-næse-hals-afdelingens opvågningsstue, der administrativt hører ind under observationsafsnittet. Hun medgiver gerne, at hendes smertebehandling er „large“. I modsætning til observationsafsnittet, hvor man kun giver fentanyl, hvis patienterne scorer 7-10 i smerte, så er fentanyl stort set altid hendes førstevalg. Hanne bemærker, at hvis hun skulle følge retningslinjerne, ville hun simpelthen ikke kunne smertedække tilstrækkeligt og effektivt. På opvågningsstuen kæmper de også med et andet problem, nemlig de postoperative patienters tilbageholdenhed med hensyn til smertestillende medicin. Især ældre patienter opfatter det ,at tage smertestillende medicin“ som udtryk for svaghed. Sygeplejersken Lene forklarer, at de af og til er nødt til at sige til patienten: „Nu 
synes jeg, du skal have lidt mere smertestillende - modsætter du dig det?“ De sociale normer og stereotype forestillinger om korrekt smerteadfærd sættes altså til forhandling i den akutte smertebehandlingspraksis, hvilket denne lille historie også illustrerer. Hanne fortæller:

Vi havde en ældre herre, der virkede forpint, men ikke ville have smertestillende, for som han sagde: 'Det skal jo gøre ondt!' Jeg forsøgte at alliere mig med konen, men hun bekræftede bare, at manden aldrig tog medicin. Til sidst pressede jeg virkelig på og overtalte ham til at få en enkelt dosis fentanyl med forklaringen 'lidt hurtigtvirkende morfin til at dæmpe den værste smerte'. Da der var gået fem minutter, vurderede jeg, at han stadig havde brug for mere - han rynkede stadig panden - så jeg gav ham $5 \mathrm{ml}$ morfin. Patienten protesterede og sagde: 'Hov hov, du sagde én gang!', men jeg skyndte mig at svare: 'Jamen, dette er en del af den pakkeløsning, du sagde ja til!' Patienten får det nu meget bedre, han kan både drikke og snakke. Da han er på vej ned på sengeafdelingen, spørger jeg: 'Jeg har lige den sidste portion her [de resterende $5 \mathrm{ml}$ morfin i ampullen], skal du have den med ned på afdelingen?' Patienten siger: 'Så giv mig den da!' (feltnoter fra opvågningsstuen).

På det danske hospital kan man se, hvordan objekter og subjekter opstår og formes af hinanden i en kontinuerlig proces (Latour 2000:196) - her skabes personer med helt bestemte sindstilstande, smerter, sorger og glæder. Hanne forsøger at rykke patientens holdning gennem det korte behandlingsforløb, fordi hans adfærd er uhensigtsmæssig set i relation til det nye smerteparadigme, hvor postoperativ smerte ikke skal tåles. Hendes historie handler om omvendelse. Før var patienten en af disse stoiske, hårdføre mænd, der signalerede styrke og selvkontrol ved ikke at bruge medicin. I det sociale spil, der udspiller sig omkring smertebehandlingen, benytter Hanne den velkendte kulturstereotyp som en slags valuta (Herzfeld 1993: 72). Hun bruger midlerne fentanyl og morfin til at overbevise patienten om, at han ikke skal bide smerten i sig, selv om han er socialiseret til det. Omvendelsen handler nemlig ikke om, at patienten skal slippe kontrollen med smerten - tværtimod. Smertebehandlingen i dette felt får netop patienternes adfærd til at leve op til sociale normer om rationel, kontrolleret og rolig smerteadfærd. I forsøget på at stoppe smerten, før patienten overhovedet ved, hvad det vil sige at have ondt, stræbes i lige så høj grad efter en normaltilstand af rolighed, afslappethed, fravær af dramatik, irritation, smerte og ubehag, hvor patienterne kan være "sig selv". Mens en ny form for viden om smerte erstatter gamle opfattelser, og smerten forsvinder, forbliver smerteudtrykket på observationsafsnittet således en diskret rynke i panden på den typiske dansker. 


\section{En udfordring}

Da antropologen Mark Zborowski studerede immigrantgrupperne på Veterans Administration Hospital i New York i 1950'erne, byggede han sin analyse på den grundlæggende tese, at folk ikke udelukkende reagerer individuelt på smerte, men kulturspecifikt: „Mennesker reagerer ikke kun på smerte som individer, men også som italienere, jøder, negere og nordboere“ (Zborowski 1969:20). ${ }^{4}$ Han så således individernes etnicitet og nationale oprindelse som indbyrdes fællesnævnere og observerede ud fra dette perspektiv, at tredjegenerationsamerikanere var objektive, upersonlige og halvvidenskabelige (op.cit.:81) i deres måde at udtrykke smerte på, hvorimod de italienske immigranters smerteadfærd var udpræget spontan, uhæmmet, larmende og ukontrolleret (op.cit.:136-44). Med repræsentationsdebatten og den litterære vending $\mathrm{i}$ antropologien er det blevet nærmest uacceptabelt at tale om sådanne kulturelle fællesnævnere (Hastrup 2004:9). Et tydeligt eksempel ses af kommentaren til Zborowskis værk i introduktionen til antologien Pain as Human Experience: An Anthropological Perspective (Good et al. 1994):

Vi rødmer, når vi læser disse beskrivelser i dag. De fremstiller stereotyper $\mathrm{i}$ stedet for at beskrive rigtige mennesker. På trods af deres gode intentioner og de små forskelle på grupper, som muligvis (eller muligvis ikke) udtrykkes $\mathrm{i}$ beskrivelserne, har disse etniske karikaturer ringe fortolkningsværdi og er nær sagt umenneskeliggørende [...]. Hans [Zborowskis] arbejde førte en generation af socialvidenskabsmænd og sundhedspersonale ind $\mathrm{i}$ en begrebsmæssig og metodisk blindgyde (Kleinman et al. 1994:2). ${ }^{4}$

I den antropologiske smerteforskning har man i stedet agiteret for en selvbevidst, metodisk tilgang, der trækker på hermeneutik og narrativ analyse i bestræbelsen på at gøre op med de kulturelle stereotyper (op.cit.:19), men folk/behandlere/ informanter taler tilsyneladende stadigvæk om sydlændinge og nordboere som henholdsvis åbne og lukkede, varme og kolde, dramatiske og indestængte, pylrede og udholdende, irrationelle og rationelle - præcis som i 1950'erne (Zborowski 1969:4). Den fænomenologiske dyrkelse af det særegne og unikke i smerteoplevelsen gør det svært for antropologien at udfordre sundhedspersonalets essentialistiske kulturrepræsentationer, fordi det interaktionelle perspektiv mangler. Spørgsmålet er, om antropologien er tjent med at undgå enhver form for kulturel teoretisering på dette punkt. På linje med socialantropologen Michael Herzfeld vil jeg mene, at kulturstereotypers virkningsfuldhed ikke ligger i anerkendelsen af en uforanderlig virkelighed, men i deres appel til den kollektive selvrepræsentations konventionelle regler (Herzfeld 1993, 1997). Patienters smerteadfærd bunder ikke i en primordial, iboende kultur, men deres måde at kommunikere smerte på er påvirket og formet af kollektive forestillinger om korrekt og pas- 
sende smerteadfærd. En anden vigtig pointe, man bør holde fast i, er, at selv om behandlere, patienter og pårørende spiller aktive roller i definitionen af socialt acceptabel smerteadfærd, så er de ikke ene om at forme smerteoplevelsen og smerteudtrykket. I behandlernes og patienternes interaktion er instrumenter, udstyr, stoffer, retningslinjer og paradigmer med til at dele ansvaret for deres handlinger og adfærd. På spørgsmålet - påvirker kulturen smerten? - må man derfor uvægerligt svare ja og tilføje, at smerten påvirker kulturen!

Min konklusion må være, at et ANT-perspektiv kan udfordre kulturbegrebets brug og implikationer i sundhedsvæsenet, selv om man næppe skal gøre sig forhåbninger om, at folk af den grund holder op med at tale om stereotype indvandrere og vestjyske landmænd. En konstrukturalistisk og relationistisk forståelse af smertebehandling er derimod nødvendig i den del af sundhedsvæsenet, der reflekterer over teknologiens og videnskabens konsekvenser. Her dyrkes primært en evolutionistisk vidensopfattelse, hvor nye former for smertebehandling italesættes som ,en overgang fra middelalderen til det 21. århundrede“ (Aken \& Buerkle 1998:253), ${ }^{4}$ og aktørerne føler sig 30-40 \% bagud, jf. den italienske anæstesiologs betragtninger. Det er godt at være ude, men hjemme er nu bedst - vil en tilsvarende dansk anæstesiolog måske tænke, hvis han læser komparationen mellem Danmark og Italien. Og dog, i Danmark er debatten om smertebehandling delt i to: På den ene side beskrives Danmark som værende helt i front inden for smerteforskning og smertebehandling (Ebdrup 2004a), mens man på den anden side problematiserer forbruget af smertestillende midler, der i løbet af det sidste årti er steget „dramatisk“ (Ebdrup 2004b). „Vi har snakket om det i mange år, men forbruget bliver bare ved med at vokse. Nu er vi nødt til at dykke ned i det og finde årsagerne", siger smerteforsker Anders Schou Olesen til Dagens Medicin i 2004. Tre år efter er det smerteforsker Per Sjøgrens tur til at sætte „konkrete tal på nationens alarmerende indtag af vanedannende painkillers“ (Benarroch 2007). At $3 \%$ af den danske befolkning regelmæssigt bruger morfinpræparater, giver Sjøgren anledning til at tale om smertelidelser som kulturelle epidemier. Selv om Sjøgren er opmærksom på, at smertelindring er „big business“ (ibid.), mangler han at drage den sociale kobling mellem udbud og efterspørgsel. Et nyt dansk studie af unge, københavnske pigers brug af hovedpinepiller har netop vist, at midlerne bliver brugt til , at tjene højt værdsatte performans- og deltagelsesrelaterede funktioner“ (Hansen et al. 2008). ${ }^{4}$ Det ville være interessant at få belyst det alarmerende danske forbrug af smertestillende medicin i relation til det nye smerteparadigme og gammelkulturelle kodekser for smerteadfærd. 


\section{Noter}

1. Samtlige sted- og personnavne er anonymiseret.

2. Dele af diskussionen i denne artikel er behandlet mere udførligt i magisterkonferensafhandlingen Et skrig af cegte smerte? En antropologisk analyse af tilgange til smerte (Tørring 2005).

3. Fentanyl er et syntetisk opioid, ${ }^{5}$ ca. 100 gange stærkere end morfin. Maksimal effekt efter 2040 minutter, to timers virkningsvarighed, stærkt respirationsdeprimerende (Infomatum A/S).

4. Citatet er oversat fra engelsk til dansk af forfatteren under vejledning af korrespondent Eva Højmark og professor Morten Pilegaard.

5. Opioider er en klasse af stærke smertestillende midler, med morfin som det mest kendte. Betegnelsen omfatter såvel de naturligt forekommende som de syntetisk fremstillede. Fælles for alle stofferne er, at de kan binde sig til de opioide receptorer i kroppen og er afhængighedsskabende.

6. Denne påstand er bekræftet af Rigshospitalets Klinik for Plastikkirurgi og Brandsårsbehandling over telefonen under feltarbejdet, september 2003.

7. Morfin er en ren opioidagonist. Maksimal effekt efter 1-1/1/2 time, virkningsvarighed fire-fem timer (Infomatum A/S)

8. Zofran er et antikvalmemiddel, der ofte gives mod bivirkninger af morfin (Infomatum A/S).

9. Dormicum er et hypnotikum af benzodiazepingruppen (sovemedicin). Et beroligende stof, der gives, hvis patienten er meget anspændt. Mange sygeplejersker påpeger, at anspændthed er hyppig årsag til „uforklarlige“" smerter (Infomatum A/S).

\section{Litteratur}

Aken, Van \& Hartmut Buerkle

1998 Acute Pain Services: Transition from the Middle Ages to the $21^{\text {st }}$ Century. European Journal of Anaesthesiology 15(3):253-4.

Benarroch, Jane

2007 Det gør bare ondt. Av! Weekendavisen 24. august, Ideer:1-2.

Baszanger, Isabelle

1998a Inventing Pain Medicine. From the Laboratory to the Clinic. New Brunswick: Rutgers University Press.

1998b Pain Physicians: All Alike, all Different. I: M. Berg \& A. Mol (eds.): Differences in Medicine. Unraveling Practices, Techniques, and Bodies. Durham: Duke University Press.

Carr, Daniel B.

1993 Pain Control: The New "Whys" and "Hows". Technology and Health Care 10(3): 227-35.

Chestnut, David H.

2000 How do we Measure (the Cost of) Pain Relief? Anesthesiology 92(3):643-5.

Chinellato, Alessandro, Gianni Terrazzani, Tom Walley \& Pietro Giusti

2003 Opioids in Italy: Is Marketing More Powerful than the Law? The Lancet 362(9377):78. 
Davitz, Joel R.

1969 The Language of Emotion. New York: Academic Press.

Donovan, Marilee, Paula Dillon \& Lora McGuire

1987 Incidence and Characteristics of Pain in a Sample of Medical-Surgical Inpatients. Pain 30(1):69-78.

Ebdrup, Mette

2004a Smerteområdet skal gøres attraktivt for unge læger. Dagens Medicin 29. januar.

2004b Forbruget af smertestillende midler stiger DRAMATISK. Dagens Medicin 29. januar.

Ehlich, Konrad

1985 The Language of Pain. Theoretical Medicine 6(2):177-87.

Finkler, Kaja

1994 Women in Pain. Gender and Morbidity in Mexico. Philadelphia: University of Pennsylvania Press.

Free, Mary M.

2002 Cross-Cultural Conceptions of Pain and Pain Control. Proceedings, Baylor University Medical Center, 15(2):143-5.

Frølund, Flemming

1996 Behandling af akutte smerter. I: F. Frølund (ed.): Smerter. En almen medicinsk oversigt. Købehavn: Arkiv for praktisk lægegerning.

Good, Mary-Jo DelVecchio, Paul E. Brodwin, Byron J. Good \& Arthur Kleinman

$1994 \quad$ Pain as Human Experience. An Anthropological Perspective. Berkeley: University of California Press.

Gould, T.H., D.L. Crosby, M. Harmer et al.

1992 Policy for Controlling Pain After Surgery: Effect of Sequential Changes in Management. British Medical Journal 305(6863):1187-93.

Hansen, Dana L., Ebba H. Hansen \& Bjørn E. Holstein

$2008 \quad$ Using Analgesics as Tools: Young Women's Treatment for Headache. Qualitative Health Research 18(2):234-43.

Hastrup, Kirsten

2004 Antropologiens vendinger. I: K. Hastrup (red.): Viden om verden. En grundbog i antropologisk analyse. København: Hans Reitzels Forlag.

Hatfield, Anthea, Michael Tronson \& Frans Lærke Bødker

2003 Opvågningssygepleje. I teori og praksis. København: Nyt Nordisk Forlag.

Helman, Cecil G.

2000 Culture, Health and Illness. 4. udgave. Oxford: Butterworth-Heinemann.

Herzfeld, Michael

1997 Cultural Intimacy. Social Poetics in the Nation-State. New York: Routledge.

1993 The Social Production of Indifference. Exploring the Symbolic Roots of Western Bureaucracy. Chicago: University of Chicago Press.

International Narcotics Control Board (INCB)

2001 Report for 2000. New York: United Nations. 
Infomatum $\mathrm{A} / \mathrm{S}$

Medicin.dk. Elektronisk dokument, adgang 31, januar 2008. http://

www.medicin.dk/(asqym555zclas45530dlqw45)/show.aspx.

Kehlet, Henrik

1989 Surgical Stress: The Role of Pain and Analgesia. British Journal of Anaesthesia 63(2):189-95.

Kleinman, Arthur, Paul E. Brodwin, Byron J. Good \& Mary-Jo DelVecchio Good

1994 Pain as Human Experience. An Introduction. I: M-J.D. Good, P.E. Brodwin, B.J. Good \& A. Kleinman (eds.): Pain as Human Experience. An Anthropological Perspective. Berkeley: University of California Press.

1998 The Illness Narratives. Suffering, Healing, and the Human Condition. New York: Basic Books.

Kleinman, Sherryl \& Martha A. Copp

1993 Emotions and Fieldwork. Newbury Park: Sage.

Latour, Bruno

1999 We have Never been Modern. New York: Harvester Wheatsheaf.

2000 Pandora's Hope. Essays on the Reality of Science Studies. Cambridge, MA: Harvard University Press.

Leavitt, John

1996 Meaning and Feeling in the Anthropology of Emotions. American Ethnologist 23(3):514-39.

Loeser, John D. \& John J. Bonica

2001 Bonica's Management of Pain. Philadelphia: Lippencott Williams \& Wilkins.

Melzack, Ronald

1993 Pain: Past, Present and Future. Canadian Journal of Experimental Psychology 47(4):615-29.

Rocca, Gino

2006 Jeg kommer så fra en pylrenation. Weekendavisen 19. maj, Opinion:10.

Rosaldo, Renato I.

1984 Toward an Anthropology of Self and Feeling. I: R.A. Shweder \& R.A. Levine (eds.): Culture Theory: Essays on Mind, Self and Emotion. Cambridge: Cambridge

Salomon, $\mathrm{Ib}$

2003 Kulturen påvirker smerten. Smerter udtrykkes vidt forskelligt fra kultur til kultur. Krop \& Fysik 4:10-1.

Scarry, Elaine

1987 The Body in Pain. The Making and Unmaking of the World. New York: Oxford University Press.

Tørring, Marie Louise

$2005 \quad$ Et skrig af ægte smerte? En antropologisk analyse af tilgange til smerte. Mag isterkonferensspeciale. Afdeling for Antropologi og Etnografi. Århus: Aarhus Universitet.

Zborowski, Mark

1969 People in Pain. San Francisco: Jossey-Bass behavioral science series.

Zenz, Michael \& Anne Willweber-Strumpf

1993 Opiophobia and Cancer Pain in Europe. Lancet 341(8852):1075-6. 
